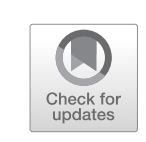

\title{
Introduction: The Rise of Nativist Populism
}

On the eve of 9 November 1989 the Berlin Wall came tumbling down. During a press briefing that night, the spokesman for the Politburo of the Socialist Unity Party in the German Democratic Republic (DDR), Gunther Schabowski, announced a plan to open the gates to the West. After delivering the statement, Schabowski found himself pressured on the question of when the policy would be put in place. He fumbled for a while, before finally replying: 'as far as I know-effective immediately, without delay'.

Schabowski had not been involved in the preparations. Only just minutes prior to the press conference had he been handed a note on the change, but he did not know that the plan was first to take effect the following day, so as to prepare for orderly implementation. For instance, the border guards had not been properly informed.

The regulation had only been agreed few hours earlier, in response to mounting pressure which was building after Hungary had begun to dismantle its border infrastructure with Austria. Many East Germans had been fleeing over to the West via that route, in ever increasing numbers. However, several of them were being detained and forcibly returned by Hungarian authorities, leading to large scale public protests within the DDR. Starting on Monday nights in front of the St Nicholas church in Leipzig, and soon also in Dresden, the crowds were calling for the gates to be opened. Gradually the protest spread around the country, eventually accumulating in large numbers on and around Alexander Platz in Berlin. Their chant grew louder; 'Wir wollen raus!' (We want out!)

E. Bergmann, Neo-Nationalism, https://doi.org/10.1007/978-3-030-41773-4_1 
Schabowski's hesitant reply, which we later learned was premature, marked the end of the Cold War system. After the announcement on TV, the crowds immediately rushed to the Bornholmer Strasse crossing. Others ran down Unter den Linden - the majestic boulevard leading from Alexander Platz to where the Wall surrounded the landmark Brandenburg Gate. There they started to tear the wall down, initially-quite literallyjust with their bare hands. The border guards had not been warned of the avalanche of protestors arriving, but luckily, they did not open fire with their fully loaded firearms. Change was in the air. Through the night Ossis and Wessis were embracing and dancing together on top of the wall, celebrating their sudden-found unity. The following day saw the dawn of a new political order.

I myself was standing in the living room at home in eastern Reykjavik, watching these dramatic events on TV. Barely twenty years old, I struggled to understand the meaning of the moment. Still, I remember it dawning on me that history was unfolding before our eyes, and that this was indeed pivotal.

Although the writing on the wall for the eventual downfall of the communist regimes was perhaps becoming increasingly apparent, and that the DDR and even the entire Eastern bloc was not sustainable, the fall of the Wall was surprisingly sudden to most people. The swiftness of it reminds us of how established political systems that we grow used to, and even start to take for granted, can come to an end-sometimes quite rapidly as was the case with the Berlin Wall and the communist structure in Eastern Europe. It can be useful to bear that lesson in mind when mapping the progression of nativist populism over the last half century-which is the aim of this book. Before delving into the meaning of nativist populism, I first turn to briefly discussing the liberal democratic order of our time.

\section{Liberal Democracy}

The end of the Cold War prompted many people to contemplate the nature of the coming political order in the West. One of the most influential intellectuals was the American political scientist Francis Fukuyama (1992). In his book, The End of History and the Last Man, he argued that the Western order of liberal democracy, reaching across the Atlantic from North America to Western Europe, would prevail for the foreseeable future. He wrote that we might not only be witnessing the end of the Cold War, an identifiable period in political history, 'but the end of history 
as such: that is, the end point of mankind's ideological evolution and the universalization of Western liberal democracy as the final form of human government' (Fukuyama 1989).

Fukuyama firmly believed in the resilience of democracy, which, he claimed, had since the French Revolution proven to be a superior system of government. With alternatives out of the way after the collapse of communism the period of dialectic contrasts and ideological conflicts, such as those identified by Friedrich Hegel and Karl Marx, was, he argued, over. In using the term 'the end of history' Fukuyama was not arguing that events would stop occurring, but that politics would predominantly be conducted within the framework of liberal democracy, that is, within the parameters of representative democratic governance in an open and free market economy.

For the West, the end of the Second World War marked the foundation of a new world order. Although the outer parameters of the post-war era were framed by the global Cold War system, the West united internally around a new political construction: the liberal democracy of independent states within a vast international architecture. This new order was to replace the fallen model of insulated sovereign nation-states, which in two world wars had left Europe in ruins. The new post-war order was partially to be regulated by international law and external authorities that in some instances overreached internal national autonomy. An era of unprecedented level of international integration emerged.

Cross-border institutions included the Organization for Economic Co-operation in Europe (OEEC), the Bretton Woods agreement establishing the World Bank (WB), and the International Monetary Fund (IMF). In 1949, both the United Nations (UN) and North Atlantic Treaty Organization (NATO) were founded. The European integration process began in the early 1950s, leading to the supra-national European Union (EU) of today. From the outset, the integration process was a conscious attempt to intertwine interests across borders in Europe so tightly that any military invasion would only hurt one's own interests.

In the following three decades, these institutions, firmly tying crossborder co-operation into a joint international framework, contributed to the increased prosperity and rapid economic growth which the region enjoyed until the Oil Crisis hit in the early 1970s. 


\section{New World Order(s)}

The significance of this change to the international system was perhaps of a similar magnitude to the Westphalian order of sovereign states that was established after the end of the Thirty Year's War in the seventeenth century. The peace agreements signed in the cities of Osnabrück and Munster in Westphalia in 1648 instated a new principle of international law, a mutual recognition of each state having exclusive sovereignty within own territory. This created the system of independent and sovereign states, refusing all rights of external state interference across borders.

Instead of continuing intra-continental conquests, European countries embarked on expansions elsewhere, leading to much further colonialization than before. In the following decades and centuries, Europeans were conquering the world. Much later, as I will explore in this book, this endeavour would result in massive migration from the colonies to the West. Finally, by the outbreak of the Great War in 1914, this Westphalian order had collapsed.

It can be argued that the institutional framework instated after the end of the Second World War in 1945 similarly created a new international order. Again, after another thirty years of conflict-between 1914 and 1945-a neoteric state order was to replace the fallen one.

As I will discuss further in the following chapter, the new post-Second World War system rested no longer solely on a principle of insular sovereign states, but - vitally for the story told on these pages-a new international institutional architecture was added to it. This change, instead, turned states interdependent. Sovereignty, as such—as a concept—gained an outer layer. It no longer solely revolved around a monopoly of internal authority, but also rested on a right that only independent states enjoyed, that of participating in international operations and pooling their sovereignty in shared institutions.

\section{Shared Values}

In the post-Second World War era, nationalism and nativism had not only come to be considered a discredited ideology, but such sentiments were even widely and firmly held in contempt. Nationalism was in this era equated with racism, and world leaders were adamant in insulating contemporary society from its toxic nature. The very term itself came to be 
understood as being pejorative. To be called a nationalist was a synonym for being racist and even being sympathetic to fascism and Nazism.

The system built after the devastations of fascism and Nazism was based on several broadly shared liberal values. In addition to increased systemic cross-border state co-operation and pooling of sovereignty, as I have already mentioned, they also included, for example: the rule of law, firm division of power, free trade across borders, respect for human rights, wide reaching civil rights, unbiased and professional administration, and a free and independent media. These were some of the basic rules of Western liberal democracies, respected across the political spectrum, from left to right. Politics, thus, did not challenge this commonly accepted frame. Rather, political adversaries campaigned for advancing their policies firmly within these parameters. In other words, these were the outer limits of partisan pursuits.

The new post-war order thus not only rested on democracy as such, but also on liberal rights, that is, civil liberties and human rights. The system relied equally on both these pillars. The liberal aspect was built in to protect individuals and minorities from oppression from the majority. Liberal democracy therefore not only insists on majority rule, but, equally - and indispensably - on minority protection. The system actively and persistently counters collectiveness. In its essence, it instead celebrates human diversity.

\section{Migration}

The post-war order brought escalated decolonialization. It was no longer deemed moral for the West to control a vast colonial system around the globe. However, Europe was at the same time in need of workers to help resurrect its economies-including the physical work of rebuilding the continent out of ruins. Most of the countries on the Western side of the Iron Curtain thus welcomed large number of foreign labourers.

In the 1960s migrants were flocking to Europe from places like Turkey, India, Pakistan, northern Africa and the Caribbean. Many came from far away colonies-former and present-of the respective European countries, bringing with them a new cultural flavour to the continent. As I will analyse further in the following chapter, collectively this was a liberal internationalist and, indeed, a multicultural response to the devastations of war caused by nationalism. 
Europe came late to the game of mass migration. Rather, it had previously been a continent of emigration. A vital part of the national identity in the United States, on the other hand, was in being a nation of immigrants, mainly from Europe. Correspondingly to that fact, the US had until recently operated a relatively liberal immigration policy.

With the fall of the Berlin Wall, Francis Fukuyama thought that the system of liberal democracy within a shared international architecture, that had proved to be so prosperous for the West, would simply be exported to replace the communist system in Eastern Europe-that is, the end of history. For a while that was indeed how it seemed. Despite serious troubles such as the Yugoslavian War, the 1990s were in many respects the heydays of liberal globalization. Several scholars started to predict the end of the nation-state. German philosopher Jürgen Habermas (1998) for instance wrote an influential essay outlining a post-national constellation of Europe.

\section{ILLIBERAL DEMOCRACY}

Three decades on, however, we now know that the story was not to be that rosy or that simple. The promise of 1989, of ever-increasing and globally spreading liberal democracy, did not materialize. Despite the multicultural and integrationist response to devastations of the two world wars, nationalism was still always an undercurrent in the post-war years, though perhaps mostly dormant at first.

Over the years that have passed since this auspicious outlook for the future was presented by Fukuyama and many others in wake of the downfall of the Berlin Wall, populist political parties have emerged in many parts of the continent. Several of them were established to contest precisely that same post-war liberal order as Fukuyama predicted would finally prevail.

As for example Yascha Mounk (2018) has pointed out, one of the defining features of the populist political actors discussed in this book is found in their disrespect for this shared framework of the liberal democratic post-war order. Many of them have based their entire claim to power precisely on their willingness to undermine core norms of liberal democracy.

It is exactly in their willingness to dispose of these shared democratic values where populists most clearly depart from mainstream parties and break away from the status quo. Indeed, much of their appeal comes from challenging the established post-war system — in fighting against what they brand as being the establishment. 
Put more simply, these can be seen as challenges to what we deem being proper and professional politics. Cas Mudde and Cristóbal Kaltwasser (2017) view this conjuncture as a 'illiberal democratic response to undemocratic liberalism'. Mounk (2018) furthermore labels this stream of thought as a bifurcation of liberal democracy, giving way to two new regime forms: illiberal democracy-democracy without rights; and undemocratic liberalism-rights without democracy.

An illustrative example of this change-when shared rules of political conduct are being contested-is found in an ongoing move away from merely seeing political opponents as adversaries who are competing within a level playing field and according to shared rules. Instead, opponents are increasingly being turned into enemies. As political theorist and former leader of the Liberal party of Canada, Michael Ignatieff (2013), wrote, 'an adversary is someone you want to defeat. An enemy is someone you have to destroy.'

In voicing their willingness to dismiss these formerly universal democratic values in the post-war era, the populists often accuse the establishment of betraying the people into the hands of foreigners.

\section{The Populist Rise}

In the summer of 2019, the ship Sea Watch docked in Italy after having rescued to safety forty Africans out of the sea near Libya. Its young captain, Carola Rakete, did not receive a hero's welcome for her humanitarian efforts. Instead, she was brought to jail where she would await trial for bringing illegal migrants to port. In a stream of angry tweets, Italy's nativist populist Interior Minister, Matteo Salvini, called Rakete a pirate and an outlaw. It is telling for how far from the liberal democratic promise of upholding human dignity, irrespective of colour or kind, the world had gone, that Rakete was but one of several humanitarian workers that faced similar hostility for the crime of rescuing people. In effect, Rakete and other rescuers were incarcerated for humanitarianism.

As I will discuss at length throughout this book, populist politics have evolved in varying ways across the different areas in Europe. For instance, they have progressed very differently from north to south, and panned out almost poles apart in old Western Europe and the former communist East.

The first prominent post-world-war movements tapping into nationalist thought in Western Europe had arisen in opposition to over-taxation and multiculturalism in the wake of the OPEC Oil Crisis in the 1970s. In France, 
the colourful demagogue Jean-Marie Le Pen founded the National Front (Front National-FN) in 1972, aiming to unify a variety of French nationalist movements. The party was constructed directly in opposition to postwar multiculturalism and immigration.

Meanwhile a somewhat different kind of right-wing populism was simmering underneath the surface in Denmark and in Norway. Protesting against rising tax levels, the Danish and Norwegian Progress Parties promoted anarcho-liberalism and campaigned against the increased economic and bureaucratic burden on the ordinary man. They argued against wide scope social services, immigration and cosy consensus politics in these corporatist social-democratic welfare states.

Prior to that, exclusionist and highly nationalist parties had existed in the Alp countries: the Swiss Peoples Party and the Austrian Freedom Party. In Finland an agrarian populist party had been established in 1959. Still, it was only after the Oil Crisis in the early 1970s that a significant wave of nativist populism arose in Europe.

The National Front in France and the Progressive Parties in the Nordic countries were not established around the traditional right-wing neoliberal rhetoric, but rather they were a new populist version of it, where charismatic leaders positioned themselves alongside the blue-collar public and against the political elite. These movements offered an alternative voice to the mainstream in politics, tapping into the fears of the ordinary public. A vital component of their rhetoric was to accuse the ruling elite of having abandoned these ordinary folk.

Over in America, the so-called Neoconservatives were around the same time gaining ground within the Republican Party. In opposition to the social-liberal tide of the late 1960s and early 1970s the Christian right wanted to revert back to protection of more orthodox family values at home, and a more aggressive approach abroad.

Prior to the collapse of communism, in the wake of the downfall of the Berlin Wall in 1989, right-wing populism was kept firmly on the fringe of European politics. For example, the National Front was in its early years isolated far out on the periphery of French politics,

When Fukuyama was predicting the longevity and universality of Western liberal democracy, there was still no indication of the later surge of rogue nativist populist actors in Western politics, as was to occur in the coming years and decades, which has accumulated into the $\mathrm{Neo}^{-}$ Nationalism analysed in this book. 


\section{Prevalence}

Much of the early literature on populist parties predicted their rapid demise. The opposite has proved to be true. Since the late 1990s, populist parties who contest core norms of liberal democracy have been on the rise, and their support in Europe has more than tripled over the past two decades. The National Front (now the National Rally) has, for instance, increasingly gained influence and remained a force to be reckoned withoften even dominating the discourse in French politics.

Populists had graduated to power in at least a dozen European countries, and such parties were in power in all of the four largest democracies in the world: India, the United States, Indonesia and Brazil. Yascha Mounk and Jordan Kyle (2018) calculated that forty-six populist leaders had reached power in thirty-three democracies since 1990. Their study found that populists in power were prone to erode democratic norms and to make changes within constitutions for their own benefits, for instance by reducing checks and balances, removing term limits and gerrymandering constituencies. Populists in power were also found liable to limit both academic and press freedoms.

Populists have also become more skilful in holding on to power. A study published by the British daily the Guardian found that the number of populists in politics had more than doubled since the early 2000s (Lewis et al. 2019). Freedom House, the independent US-based watchdog monitoring the state of democracy and civil liberties around the world, concluded that democracy was in decline, and that more countries were moving away from democracy than stepping towards it. ${ }^{1}$ The same applied to citizens' views. Fewer in the West were now found to agree with the statement that it was important to live in a democracy. And more people supported strongmen-leaders than before. A report published by the Bertelsmann Stiftung in Germany found that restrictions on political freedom were increasing, and that world governments were rather curtailing democratic norms and practices than strengthening them (Schwarz 2018).

One of the first country leaders of this nature was the flamboyant neoliberal, and at least semi-populist, Silvio Berlusconi, who brought his Forza Italia to take control of Rome in 1994. His focus on controlling the media proved successful and was later mirrored by others, in what was branded the Berlusconization of politics. ${ }^{2}$ Donald Trump was for instance later to adopt many of his qualities. 
In Austria, Jörg Haider was also turning the Freedom Party in a sharp populist direction, eventually landing in government. This he did by tapping into the fears and emotions of the ordinary public, while avoiding the more intellectual debates. With active and systematic help from the tabloid media he set his sights on the domestic elite, who he argued were betraying the people into the hands of an external threat. This mounting threat, he found, stemmed from foreign migrants entering Austria in increased numbers at the time.

The Guardian found that populist parties had surged from barely bagging 7 per cent of the vote on average in nation-wide elections in the late 1990s, to winning one-quarter of the vote by 2018 (Lewis et al. 2018). Already in the 1990s, nativist populism was, however, taking a new form in many European capitals.

\section{TRANSMISSION}

Recent years and decades have seen the renaissance of nationalism in the West. Contrary to Fukuyama's predictions, nativist populism was only to grow stronger and spread further. Its transmission was further fuelled by the emergence of the 24 -hour broadcast news media. In addition to that the proliferation of online media, especially social media, windswept the gate-keeping role of mainstream media of the twentieth century. Populist rhetoric spiked once again in the wake of the financial crisis starting in 2008. It also snowballed south, often taken on a more leftist form.

The era of conspiratorial populists has furthermore led to the emergence of what has been branded post-truth politics, where the overflow of information drowns out facts and public discourse appeals rather to emotions and personal belief (Bergmann 2018).

Society is now flooded with an avalanche of indiscriminate information, under which people cannot easily separate facts from fabrications. This opens up a space for misinformation to thrive, leaving democratic societies vulnerable to manipulation. As result, modern media has brought increased polarization, which has proved to be rather favourable to the rhetorical style of populist communicators.

In 2014, right-wing populist parties won a record number of votes in the European Parliament (EP) elections. In the 2019 vote they increased further. The period in between is when Neo-Nationalists really came to dictate much of the political agenda in the West. The year 2016 brought a double shock, with the Brexit vote in the UK and the election of Donald Trump to the White House in Washington. 
Interestingly, Donald Trump found success on a completely inverse platform to the promise of liberal democracy. The wings that allowed him to take off and dominate American politics were weaved out of material made by first, the so-called Neoconservatives, and later, the Tea Party. Contradictory to tearing down barricades, Trump was indeed largely elected on a promise of building new ones. In 1987, US President Ronald Reagan had in his famous speech in Berlin called on Soviet Union chairman, Mikhail Gorbachev, to 'tear down this wall!' Just shy of three decades later, Donald Trump — who, it is worth noting, claimed to adore Reaganpromised to build a brand-new wall, running along the entire US border with Mexico. Converse to Reagan in Berlin, the crowds at Trump rallies in the US chanted, 'build that wall!'

It was a telling moment for this political turn when Victor Orbán of Hungary said in celebration of Trump's victory that it marked America's transition from a 'liberal non-democracy' to a 'real democracy'.

In 2017 Marine Le Pen, who had succeeded her father as leader of the National Front, competed against Emmanuel Macron in the run-off to the French presidency, where she won a staggering one-third of the vote. Later that year, the anti-immigrant Alternative for Germany surged in the federal elections to the German Bundestag. Their support came on the canopy of the migration crisis of 2015 in the wake of the Syrian War. This was the first time that an anti-immigrant and far-right populist party found real a foothold in post-war Germany, where such sentiments had been forcefully suppressed after the devastations of Nazism.

In 2018, two populist parties took Rome by storm and united in a short-lived coalition. That was the first time that populists fully controlled government in one of the six founding member states of the European Union. On canopy of the Coronavirus Crisis of 2020 several nativist populist leaders in government took steps to advance their authority domestically, such as in Russia, Hungary and in Poland. Russia used the opportunity to implement a controversial massive facial-recognition system, and authoritarian government of China also enhanced surveillance of its citizens.

\section{Pathological or Practical}

Populism can be a complicated concept to comprehend. When Richard Hofstadter (1964) published his landmark book, The Paranoid Style in American Politics, the term populism-or what constituted being a populist-had not yet gained the same connotations it later contained in contemporary political studies. Still, present day populism can at least partially be fitted into his framework. As Noam Gidron and Bart Bonikowski 
(2013) point out, Hofstadter's analysis of the paranoid style in American politics, 'characterized by heated exaggeration, suspiciousness and apocalyptic conspiratorial worldview' can also shed light on the 'properties of populist politics as a discursive style'. In a somewhat similar vein, British scholar Margaret Canovan (1981) saw populism as 'the shadow of democracy'.

In Hofstadter's view, populism was merely one of many other conspiratorial fantasies emanating from the political far-right at the time. He saw the radical-right as standing psychologically outside the frame of normal democratic politics. In this regard, populism has often been explained as a sort of pathology in post-war Western societies, some sort of delusion and deviation from normal politics.

This view, however, does not always hold up in empirical testing. As will become evident in the following discussion, the spread of populism in contemporary Europe has proved to be much broader and reached further into the mainstream than can simply be dismissed or marginalized as paranoid and/or delusional. As such, populism is neither necessarily always pathological.

In fact, populism can in certain situations be seen as a sensible worldview of the deprived and powerless who are faced with a dominating capitalist order aligned against them. Populist leaders claim that politics have become increasingly alien to the people, for instance when insisting that the professionalization of politics has turned governance into a trade that ordinary folks are in effect barred from.

In that regard, populism can be viewed as a legitimate strategy in the campaign for winning back lost authority from an overtly powerful elite. Thus, populism can be a useful tool in delegitimizing established authority and power relations. In some sense, populism is thus also partly a call against professional politics. And thus, perhaps rather a call for the reamateurization of politics.

However, one of the main weaknesses of populism is found in its notion of capturing the 'will of the people'. 'The people', as such, do not possess a cohesive will. Human societies are usually not very homogeneous. Rather, they are much more diverse and do not usually display a cohesive and unified will of the people. Still, in a performative act, populists tend to create into being such a cohesive 'will of the people'. 


\section{InTo the Mainstream}

Although nativist populist movements have been established as a significant part of European politics since the 1970s, their reach has altered over time and across the continent. Initially, these were mostly white Christian men upholding conservative family values. Gradually however, women have become more prominent in many nativist populist movements than before, for example, Marine Le Pen in France, Pia Kjærsgaard in Denmark, Siv Jensen in Norway and Frauke Perry in Germany. These are, thus, no longer only angry white men. Angry white women are also rising to leadership roles within populist parties throughout Europe.

Over the years, populist parties have moved from the fringes of Western politics and found foothold firmly within the established political systems. Furthermore, after decades of marginalization in the wake of the Second World War, mainstream parties started in the 1990s gradually to abandon their adversarial stance against the populists, and in many cases instead adopted a strategy of accommodation. Formerly discredited and ridiculed parties have not only become accepted but have to a large extent emerged to dominate the political discourse. Rhetoric that was widely rejected and condemned in the wake of the Second World War has gradually crept back into the public debate.

In a process of normalization, nationalist, xenophobic and outright racist rhetorics are no longer necessarily treated as taboo, but have instead found widescale backing. Mainstream centre-right parties have for instance been found to be increasingly susceptible to views that previously were only held on the radical-right, such as of continuously adopting everstricter immigration policies.

Cas Mudde (2016) maintains that the populist radical-right constitutes a radicalization of mainstream views, that key aspects of the populist radical-right are now being shared by the mainstream. Indeed, recent years have seen the infiltration of populism into the mainstream in many countries, to the extent that it has become increasingly difficult to disentangle the two.

Populism has been deeply integrated into contemporary democratic politics. Populist rhetoric is no longer only a tool of powerless protestors and no longer merely a symptom of a crisis of democracy or crisis of faith in democracy. Rather, it is being firmly woven into democratic societies, which as result, are in many ways being dominated by the populist rhetoric. 
The use of the term, populism, spiked in 2016, in the wake of the Brexit vote in the UK and the election of Donald Trump in America, to become one of the most common in political discussions. In many ways, populism was becoming a defining element of the politics of our time. This is illustrated by the fact that the Cambridge Dictionary chose it as the word of the year in 2017.3

The process of normalization of populist politics occurs, for example, when mainstream parties follow suit in the wake of the populists, and in their quest for winning back lost supporters, themselves start to abandon the once-shared values of Western democracies. This, in turn, serves to erode the once-shared liberal democratic norms of the West.

Although often veiled, contemporary nativist populism can be traced from the fascism of a previous era. At the present time, even discredited authoritarian leaders of the past such as Benito Mussolini and Joseph Stalin are again being glorified. And notorious policies that had for a long time been collectively canned-such as religious and racial segregationare rising to the surface again. Jörg Haider of Austria's Freedom Party, for instance, dismissed much of the discussion around Austria's Nazi past. 'Our soldiers were not criminals', he said to a group of Second World War veterans, 'at most, they were victims'. ${ }^{4}$ Likewise, the leader of the Italian Lega, Matteo Salvini, openly voiced his admiration of Mussolini. And in Russia, President Vladimir Putin has repeatedly acted to resurrect Stalin's reputation.

In many Western countries, aggression against Muslims has been normalized to the extent that even many heads of state frequently uphold a rhetoric of anti-Muslim fear-mongering. The previously discredited and marginalized conspiratorial scare-mongering populism of rogue actors that were firmly placed on the periphery has graduated to become the core message spread from the very power centres themselves-for instance from the Kremlin in Moscow, the Sándor president palace of Budapest and the Oval office in Washington. When mapping the evolution of nativist populism, it is difficult to overestimate the significance of this change.

\section{VARIETIES OF Populism}

Right-wing populism is by now well established in European politics, and the literature on populism and extremism is vast and far-reaching. In fact, more academic studies have focused on far-right populism than on any other political party family combined (Mudde 2016). The phenomena 
have been studied from a plethora of different approaches, such as political science, communication studies, historical analysis, social psychology, political economy and democratic theory.

However, framing what constitutes populist politics and populist political movements can be a daunting task. As I will discuss further in the following chapter, definitions on the phenomena have been quite fleeting in the social sciences. Not only can populism be understood as either an ideology or a rhetorical style, but these are often quite different groupings holding a variety of positions which can be changeable from country to country. Most often they are constructed around respective national interests, and can also be contradictory across borders. And the different actors are sometimes at odds with each other. After the 2014 European Parliament elections, UKIP in Britain for example, refused to co-operate with the French National Front which they accused of being racist. A similar problem arose again around the EP 2019 election, when several populist actors attempted to unite the far-right in a cross-border alliance.

Many of the populist movements held neo-liberal economic policies, while some were mostly concerned with protecting the welfare system from immigrant infiltration-for the benefit of the ethnic population. This was for example the case in Scandinavia, where interestingly, populist movements in the 1970s had started out being neo-liberal. Modest versions of populist movements existed. Some were primarily nationalist. They could be far-right or what can be called extreme far-right, sometimes even a militant version denouncing democracy. Others were ultranationalist. There were those of a more neo-fascist nature, mostly found in Eastern Europe, but also in Greece and other Western European countries, such as in Sweden.

Then there were also left-wing versions. In the wake of the Financial Crisis that began in 2008, such parties for example found success in Greece (Syriza) and in Spain (Podemos). The fundamental difference between the two is that while the right was preoccupied with the interests of the ordinary public, the left was particularly concerned with the socially underprivileged. Both however unite in criticism of the political elite, for example in the European Union.

More militant versions of populism have also existed around the world, across the political spectrum from left to right. Many of the most notorious have been in South America. 


\section{Other Eras and Areas}

Most of these parties turned their gaze against diversity and social heterogeneity, the post-war internationalized architecture, and primarily opposed the increased migration that had followed. In some sense, this can entail a nostalgic wish for bringing back the collapsed Westphalian order of insulated sovereign states; a glorification of simpler times, when sovereign states were not constrained by international treaties and institutions.

However, neither nationalism nor populism were limited to Europe or the West. Indeed, versions of nativist populism have thrived around the world, for instance in Latin America, the Middle East and Africa.

In the 1890s, the People's Party of the United States (also known as the Populist Party), rallied farmers and workers against the elite. Many other populist parties followed in the US, for instance the Progressive Party founded in 1912 and led by Theodore Roosevelt, who later became US President.

Populism as such should not be conflated with extremism, although many extremist groups have applied populist means. Levitsky and Ziblatt (2018) note that around 800 extreme-right groups existed in the US in the 1930s alone. In 1938, the American diplomat and influential strategist George Kennan, for example, suggested that in line with trends in Europe, the US should turn to authoritarian rule. He suggested that voting rights should be withdrawn from all American women, immigrants and AfroAmericans. The aviation legend Charles Lindbergh sympathized with Nazi Germany. Famously he upheld the slogan 'America First'-later adopted by Donald Trump who forcefully applied it in the 2016 presidential election.

Although fascist regimes survived the Second World War in southern Europe-Spain under Francisco Franco and Portugal under António Salazar-populism was in those years generally more prominent in South America than in the West, where it developed much later. In many respects, the interwar fascism in Europe travelled to Latin America where it merged with anti-liberal and anti-communist ideology. It can be argued that the first modern post-war populists to find success were the Argentinian Peronists from 1946. The three-times Argentinian President Juan Peron built his movement on the intellectual fascism that had been prominent in the country for the previous two decades. As elsewhere, Argentinian fascists had denounced democracy. Peron's political creation was however a hybrid structure, merging corporatism with authoritative democracy. 
Peronism rejected both capitalism and communism. Known as the 'three flags', it rested on the trinity of social justice, economic independence and political sovereignty. The corporatist state was to be the powerful mediator between the conflicting interests of capital and workers. Federico Finchelstein (2017) describes Peron's regime as a 'postfascist, authoritarian, and antiliberal version of democracy'.

Many movements have since been based on a similar approach. Among actors of that ilk was for example Alberto Fujimori who served as the President of Peru in the last decade of the twentieth century. Accused of widespread corruption and severe human rights violations, Fujimori fled to Japan after seceding power in 2000 .

In 2019 the far-right populist Jair Bolsonaro was inaugurated as President of Brazil after having tapped into a similar heritage of Latin American populism. When assuming office his new Foreign Minister Ernesto Araujo said that his country would abandon globalism. Science denialism was apparent amongst many populist leaders during the Coronavirus Crisis of 2020. Bolsonaro was amongst several strongman leaders who dismissed warnings of scientists regarding impact of the disease.

On the left side of the populist spectrum, many countries in Latin America have also fallen into the hands of the radical left, such as in Venezuela and in Bolivia. Hugo Chávez's Bolivarian Revolution in Venezuela rose to power on a promise to a deprived public: that of resurrecting the destitute many against the oppression of the privileged few. Several years after coming to power in the late 1990s, Chávez rewrote the constitution and consolidated authority into his own hands. Democracy was replaced with authoritarianism and the Venezuelan economy deteriorated, leading to vast impoverishment and large-scale economic emigration.

\section{The Erosion of Democracy}

Many examples exist of democracy dying out accompanying the rise of populists or other kinds of authoritarian actors. Most obvious is where that occurs via coups d'état, such as when General Augusto Pinochet ousted Salvador Allende's democratic socialist government in Chile on 11 September 1973. Military coups have occurred in countries like Turkey, Greece, Thailand, Argentina, Brazil and Uruguay. Then there are the communist revolutions, such as when Fidel Castro seized control of quasidemocratic Cuba in 1959. During the Cold War these were indeed the most common causes of the demise of democratic states. 
Democracies have also come to an end after authoritarian leaders were freely elected. The most notorious examples of dictators abandoning the very democratic process that brought them to power are for instance Adolf Hitler in Germany and Benito Mussolini in Italy. Both were facilitated by mainstream collaborators who thought they could tame the demagogues once in office. The opposite proved to be true. Hitler used the Reichstag fire in 1933 to kill off democracy in Germany.

Traditionally, these political outsiders emerge on a canopy of a popular movement that elevates them to power. Still, in most cases they never enjoyed majority support. As Levitsky and Ziblatt (2018) note, there was for instance never any evidence of majority support for authoritarianism in Germany and Italy in the 1920s. In other words, even though the mainstream is usually in a position to stem their surge, there are instances when polarization has gone so far as in tempting mainstream actors to rather collaborate with the demagogues, than in reaching across the traditional dividing lines in domestic politics. In doing so, there are instances where mainstream actors have unwittingly facilitated the demise of democracy.

Levitsky and Ziblatt (2018) however, also list many cases during the interwar years where such an authoritarian surge was stemmed, such as in Belgium, Britain, Costa Rica and Finland. These are examples of countries where the mainstream was able to unite across political dividing lines against challenges waged from demagogues.

\section{InCREMENTAL UnADMiTTED Authoritarianism}

A subtler and less noticeable version of the erosion of democracy is the more recent phenomena of incremental authoritarianism. This is when liberal rights are submerged more slowly, such as in Russia and to a lesser extent also in Hungary and Poland. Here, the leaders often don't even acknowledge the gradual change; rather, they take to redefining what democracy really means.

This is democracy only in name. While arguing that the liberal democratic system is rigged for the benefit of the elite, a populist leader can insist that his actions, effectively eroding democracy, are instead being made in order to return power to the people. As I will illustrate further in the following chapter, the populist leader then commonly starts equating his own policies with the will of the people.

As I will also explore further throughout this book, this kind of change often occurs in the wake of a crisis. Social and economic catastrophes can 
open up a space for re-examining the foundations of political systems. This is what is sometimes referred to as a constitutional moment. Populists have proved to be especially capable in exploiting such situations for their own political gain. In addition, they have furthermore proved prone to discursively manufacture a sense of crisis among the public.

In Venezuela for instance, Hugo Chávez was able to rally support against what he called the corrupt governing elite in Caracas, promising to enrich the poor and, indeed, to replace what he called the infected and fraudulent Venezuelan democracy with a more 'authentic' democratic representation of the people. Chávez's Bolivarian revolution indeed started out on a democratic footing and there was never any popular call for autocracy. However, after pushing through his constitutional changes, which for example eliminated term limits for the president, Chávez took to dismantling liberal media, rolling back civil rights and oppressing political opposition. In 2017, Chávez's successor Nicolas Maduro took the definitive step of absorbing the power of Congress, completing the turn of Venezuela into a widely recognized autocracy.

This was a similar move to Alberto Fujimori, who however operated on the other side of the political spectrum. Via a televised address in April 1992, he killed of Congress and dissolved the Peruvian constitution.

More often though, this kind of subversion of democracy leads to more hybrid structures than the now full-blown dictatorship in Venezuela. During the Coronavirus Crisis of 2020 the prime minister of Hungary, Viktor Orbán, used the opportunity for a power grab when rushing emergency legislation through parliament, which, in effect, gave him powers to rule by decree. The legislation threatened to erode what was left of liberal democracy within the country.

\section{Democracy in Name}

In the modern version, these states commonly still bear a resemblance to democracies. Although institutions and rules of law are habitually presented as corrupt and preventing the populist leader from realizing the will of the people, democratic conventions are often rather circumvented than abolished.

The authorities still call people to the polls, the media continues broadcasting news, and some political opposition is still allowed. The domestic dissidence is however often quite contained, as has for instance been evident in Russia where political actions that might not be to the Kremlin's 
liking are closely monitored. The media is controlled, and elections are effectively rigged.

Some of these tribulations became evident to me when serving as an OSCE (Organization for Security and Co-operation in Europe) election observer in the Russian 2012 presidential election. Based in a rural area outside of Kazan in the Russian state of Tatarstan, I witnessed how the electoral process was arranged — not only by a few deviations from conventional practices, but rather in its entirety. Here are some examples. First, viable candidates that realistically could have contested Vladimir Putin had been disqualified and thus prevented from even entering the race. Secondly, voters could not be sure of the secrecy of their ballot. Web cameras had for instance been installed around the voting stations and it wasn't all that clear what they were recording. The rules forbade folding the long ballot paper sheet. And as the ballot boxes themselves were semi-transparent, the ballot sheets could in some instance be read after submission.

On top of this, we encountered representatives of Putin's party roaming around the voting stations. A few times I witnessed voters not so discreetly baring their ballot sheet to an official-looking person standing on the sidelines. In one polling station we witnessed a stern-looking man sitting in the entrance near the ballot box, scribbling something down on a piece of paper when voters passed him. We asked our driver to find out who that person was. He turned out to be a foreman in a local factory, making sure that his employees correctly cast their votes. The list of discrepancies from proper voting practices we encountered was long.

Vladimir Putin also took a page out of the playbook of some South American leaders, mentioned above, when changing the Russian constitution for his own benefit, bypassing clear term limits. Both Hungary and Poland have also entered on a journey down a similar road. How far they will go remains to be seen. In these cases, leaders have often started out respecting democratic norms, only to abandon them later. Such was the case with Victor Orbán and Fidesz in Hungary, and in Turkey as well. The consolidation of power is most commonly justified by casting opponents as posing an existential threat to society, whom they vow to protect.

In these cases, democracies die more with a whisper than with a bang, by incremental erosion of the norms that are necessary to underpin democracy. There is no single act that kills it off. No coup d'état, no armies on the streets. No one necessarily notices the time of death. In fact, as will become evident when several of these cases are discussed in the following chapters, many of the acts taken to subvert democracy are in name meant to improve it. 


\section{The Transformation of Party Politics}

Alongside the rise of populism, political party systems in Europe have been in transformation. The surge of right-wing populist is only a part of the story. Similar to the media becoming much more fragmented and polarized over the recent years, politics has also followed such a path. Election results in Europe over the past two to three decades have been increasingly volatile. This indicates a much broader pattern of societal fragmentation than is illustrated by the populist rise. The mainstream right in European politics has also become more radical, and the same has recently started to occur on the political left. Central parties have found diminished support. This process has brought the gradual demise of the centre-left/centre-right duopoly that dominated Western liberal democracies in the post-war era.

In an attempt to stem the electoral tide towards populist parties, many mainstream parties responded by following suit in a more radical and/or populist direction, reverting to partially adopting some of the populist rhetoric, thus shifting the general political discourse in the populist direction and widening what was considered acceptable in public debate. Progression of this kind has, for example, occurred in Austria, Denmark and in the Netherlands.

This trend has been especially evident within social democratic parties, who have seen support moving over to the populists. In fact, centre-left parties have lost out the most with the populist uprising. Many of their supporters have accused traditional social democratic leaders of being in bed with the capitalists. In some regard, the populist rise can be viewed as a response to the ideological convergence of mainstream social democrats and mainstream economically liberal parties. In other words, this evolution can be viewed as a protest against the 'end of history' where all mainstream parties have come to resemble one another. Cleverly, for instance, the National Front in France branded the convergence of the centre-left Socialist Party (PS) and the centre-right Union for Popular Movement (UMP) as UMPS. This indicated that both parties were indeed one and the same. As result, social democrats were relegated to diminished roles even in many of their traditional strongholds, such as in France, Denmark, Italy, Germany and in the Netherlands.

The links between the leadership of social democratic parties in Europe and their traditional blue-collar supporters started to fray back in the 1990s. Instead of focusing most forcefully on progressing the economic 
prosperity of the working class, many social democratic leaders instead became increasingly preoccupied with newer and more sophisticated political tasks, such as international integration, gender equality, professional administrative practices, democratic innovations, fine arts and higher education, as well as with environment protection. As result, many of the traditional working-class voters on the left felt politically alienated, which allowed populists from both left and right to sneak past and fill the vacuum.

More recently, this same turn was occurring within traditional rightwing conservative parties, such as in the UK. The rise of first UKIP and later the Brexit Party led the Conservative Party to become much more Eurosceptic than before, leading to the Brexit endeavour which I will discuss later in this book.

More generally, this change is also illustrated by the increased fragmentation of party systems and greater volatility in many Western states. Governments now change more frequently than before. The centrifugal nature of this trend has led to a transformation in European party politics, where centre parties were largely losing to the periphery on both sides.

\section{Distant and Aloof}

Although populism is increasingly being entangled into the mainstream, that does not dissolve the need for framing the phenomena. Irrespective of frames and competing definitions, however, populist nationalism commonly entails a nostalgic longing for bringing back the glory days of the post-war nation-state. It can thus partially be seen as a call for national restoration-if you will, a return to the nation. Ruth Wodak (2015) calls this the renationalizing of nativist tendencies. In other words, the story told on these pages, the contemporary rise of nativist populism, is one of Neo-Nationalism-which I will return to discussing further in the following chapter when examining the contemporary convergence of the otherwise distinct phenomena of populism and nationalism.

In the wake of the Second World War, the system of nation-states within a shared international architecture brought the promise of ever-increasing prosperity. Indeed, the post-war era was a period of spectacular growth and far-reaching welfare systems were instated around Western Europe. However, with growing globalization it has become increasingly difficult for governments to make good on that promise. Countries have become embedded in the same system. This has led to the gradual waning of the nation-state, a decline in national authority. 
Surely, globalization of the economy has enriched many, and even brought wide economic gain to large swaths of perhaps most populations. However, while the wealth of the richest has skyrocketed, globalization has also brought increased inequalities. This has led to distrust within society and a growing feeling among many people of their lives increasingly being dictated by a detached and aloof elite, who are no longer listening to the ordinary person. A feeling of being left behind in fast-moving contemporary society while others might be prospering has fuelled support for political actors that position themselves against the globalized liberal democratic system.

The control of public authority has to an increased extent shifted to domestic non-governmental actors such as specialists, media and financial elites. Special interest has become increasingly stronger in many Western countries, often hiding behind armies of lobbyists and public relations people who guard their interests.

Politicians and public officials often become captives of these immense special interest actors, who in many cases fund their political campaigns. In addition to that, politicians have seen their influence on unelected public bodies, such as independent agencies and central banks-and, of course, on global corporations and supra-national institutions. Then there are globalized social media conglomerates, like Facebook and Twitter, who seem to be regulated by no one.

Critiques of this change have pointed to governments becoming captured by internal and external constraints which prevent them from offering a viable and plausible future for their lower-income citizens. These critics argue that governments are no longer in control of capital, which flows across border from the nation-states-for example into booming offshore zones. This, they maintain, is causing national decay.

In positioning themselves against this convulsion of national politics, one of the Neo-Nationalists' claims to power is, then, calling for the resurgence of the nation-state, and, indeed, to free governance from the constraints of this globalized state system.

The weakness of the internationalized capital system becomes most evident in crisis, when those feeling left out from the benefits of boomperiods find themselves in further dire straits. Austerity, such as the severe measures that were instated widely in Europe in the wake of the Financial Crisis starting in 2008, brings fury against governments. Suddenly, authorities find themselves accused of not guarding their people, and, as result - thus also by default-betraying the very people they should be 
serving. This kind of feeling was mounting again in several countries during the Coronavirus Crisis of 2020.

In some sense then, we are dealing with a revolt of the underclasses who have become disillusioned with mainstream politics. This is the uprising of those who feel left out in the new liberal, high-tech and internationally connected economy. In some respect this is the roar of those who have grown frustrated with being silenced and sidelined within society.

In this situation, all sorts of chauvinists and other mischievous figures can rally support. Often they point to scapegoats, such as immigrants, who in turn become victims of irrational rage. This sort of politics thus brings a call for reaffirming borders, kicking out migrants, building walls-then a longing for strongmen leaders to guide the ordinary people out of a bad situation. Ironically, the rise of nativist populism brought the globalization of nationalism.

\section{ANTI-IMMIGRATION}

In this book I argue that contemporary nativist populism has travelled in waves, rising on the canopy of crisis. The first wave arose in the wake of the Oil Crisis of the early 1970s, and the second after the collapse of communism. The third wave rose most clearly in opposition to migrationmainly against Muslims settling in the West. Shortly after the terrorist attack in Nice on Bastille day 2016 Marion Maréchal Le-Pen, a prominent member of the National Front and a niece of the leader Marine Le-Pen, crystallized this message when she said: 'Either we kill Islamism, or it will kill us.' She added that those who choose the status quo 'become complicit with our enemies' (qtd in Riddell 2016).

Surely, this response was spurred by mass migration from North-Africa and the Middle East to Europe. Still, there was not necessarily a correlation between actual social developments and the level of support for populist parties. Among countries where these kinds of parties have found greatest support are for instance the more wealthy Switzerland and Austria. Denmark is another example of a highly successful radical-right populist party flourishing in a rich welfare state. In Britain, interestingly, many of the areas most heavily subsidized by the EU largely voted to leave in the 2016 Brexit elections.

Furthermore, both the True Finns and the Dutch Freedom Party grew stronger while immigration levels were falling in Finland and in the Netherlands. And although being almost untouched by the Refugee 
Crisis, and even also seeing economic growth at the time, populist parties were on the rise in the Czech Republic. The anti-immigrant former businessman Andrej Babis, who led the ANO party to victory, became Prime Minister. Some of the most hardened rhetoric against Muslim migration has been heard in countries where Muslims are low in number, such as in Hungary and Poland.

Many further examples exist of such discrepancies. Unlike what might have been expected, support for Donald Trump among ethnic whites was, for instance, not greater in areas with higher levels of immigration, such as in Chicago, Los Angeles and New York. Neither did the Alternative for Germany find much support in the most diverse parts of Berlin. Nor did the National Front do especially well in the most motley parts of Paris or Marseille. In fact, the contrary was true.

This suggests that actual situations around the state of the economy, immigration or other social aspects are not necessarily the main explanatory factors around the rise of nativist populism, like many have insisted. But perhaps, rather, that mere political rhetorics might here also be at play, a discourse that can mobilize anxieties and anger from certain demographics that feel left behind. As both Wodak (2015) and Mounk (2018) have argued, fear of an imagined grim future might explain as much as disenchantment with the actual living reality. In fact, as will become evident on these pages, a perceived bad situation in society compared to others is key to understanding support for nativist populist parties.

\section{The Aim and Frame of the Book}

This book maps the rebirth of nationalism in Europe and America since the Second World War, which has taken on a populist form. As I mentioned above, populism has already been vastly studied. The main contribution of this study is in separating nativist populism from other kinds within the populist family. Based on the approach of Critical Discourse Analysis (CDA), developed by for example Ruth Wodak and Norman Fairclough (2013), I will highlight discursive manipulations and structural inequities. The surge of populist politics examined in this book has indeed brought back the importance of dialectic observation, examining populism as countering mainstream politics.

The book furthermore offers two other main academic contributions. The former is a novel way of framing three waves of nativist populism in the post-war era, each examined in a separate chapter. Each wave occurred 
in the wake of crisis or major social change, and each grew stronger than the one before. All are identifiable by their own qualities and characteristics, which are analysed here. Another contribution is in identifying ten common qualities of nativist populism.

In essence, this book provides a broad overview of modern political history in Europe and in America. It covers some of the most contested phenomena in contemporary politics, focusing on nationalism, populism and right-wing extremism. Perhaps most vitally the book documents a turn away from liberal democracy established in the post-war era, and towards more authoritative illiberal modes of democracy. In some cases, such as in Hungary, Poland and Russia, authorities have already moved away from many democratic principles. Collectively, I refer to this overall trend as a turn to Neo-Nationalism.

\section{STRUCTURE}

The book is divided into six chapters. Following this Introduction, the next chapter will lay out how the Neo-Nationalism of contemporary nativist populists should be understood. In mapping their historical evolution through three waves and identifying common qualities, the book provides a context for studying the rise of nativist populists. Each of the three subsequent chapters examines one of the three waves in the post-war era.

The First Wave rose in opposition to over-taxation and multiculturalism in the wake of the Oil Crisis in the 1970s-bringing forth for instance the National Front in France and the Progress Parties in Scandinavia. The chapter furthermore explores the foundations of the post-war liberal democratic order, which nativist populists have been contesting.

The Second Wave grew out of resentment in Western Europe against workers from the eastern regions of the continent flocking over the former Iron Curtain after the collapse of the Berlin Wall in 1989. A spike within this wave occurred in the wake of the terrorist attacks in the US on 11 September 2001. This wave for instance brought Silvio Berlusconi to power in Italy, Jörg Haider to prominence in Austria, and laid the ground for the renewed rise in nationalist sentiments around Eastern Europe as well as in America.

The Third Wave was brewing in the wake of the International Financial Crisis that began in 2008. This wave brought for example Donald Trump, Brexit and illiberal democracy to Eastern Europe as well as populists to 
power in Italy. A fundamental shift occurred in the third wave with the heightening refugee crisis in 2015. Nationalist sentiments were again awakening with the Coronavirus Crisis of 2020. Whether it will lead to rise of a fourth wave of nativist populism remains to be seen.

The closing chapter traces the progression of nativist populism over these three waves, constituting a rise of contemporary Neo-Nationalism, which largely is defining our times.

\section{Notes}

1. Freedom House. 2018, 16 January. 'Democracy in Crisis: Freedom House Releases Freedom in the World 2018'.

2. The Economist. 2009. 'The Berlusconisation of Italy'.

3. Cambridge Dictionary's Word of the Year (2017).

4. BBC news. 2002, 2 February. 'Jörg Haider: Key quotes'.

\section{REFERENCES}

Bergmann, E. (2018). Conspiracy \& Populism: The Politics of Misinformation. London: Palgrave Macmillan.

Cambridge Dictionary's Word of the Year 2017. (2017, November 29). About Words-Cambridge Dictionaries Online Blog. Retrieved January 2, 2019, from dictionaryblog.cambridge.org.

Canovan, M. (1981). Populism. San Diego: Harcourt.

Finchelstein, F. (2017). From Fascism to Populism in History. University of California Press.

Fukuyama, F. (1989). The End of History? The National Interest, 16, 3-18.

Fukuyama, F. (1992). The End of History and the Last Man. New York, NY: Simon and Schuster.

Gidron, N., \& Bonikowski, B. (2013). Varieties of Populism: Literature Review and Research Agenda. Working Paper Series, Weatherhead Center for International Affairs, Harvard University, No. 13(0004).

Habermas, J. (1998). The Postnational Constellation. Boston: MIT Press.

Hofstadter, R. (1964). The Paranoid Style in American Politics. New York: Vintage Books.

Ignatieff, M. (2013). The Lesser Evil: Political Ethics in an Age of Terror. Princeton University Press.

Jörg Haider: Key Quotes. (2002, Summer). BBC News. Retrieved January 4, 2019, from news.bbc.co.uk.

Levitsky, S., \& Ziblatt, D. (2018). How Democracies Die. New York: Crown. 
Lewis, P., Clarke, S., Barr, C., Kommenda, N., \& Holder, J. (2018, November). Revealed: One in Four Europeans Vote Populist.

Lewis, P., Barr, C., Clarke, S., Voce, A., Levett, C., Gutiérrez, P., \& Gutiérrez, P. (2019, March). Revealed: The Rise and Rise of Populist Rhetoric. The Guardian. London.

Mounk, Y. (2018). The People Vs. Democracy: Why Our Freedom Is in Danger and How to Save It. Harvard University Press.

Mounk, Y. M., \& Kyle, J. (2018, December 26). What Populists Do to Democracies. The Atlantic. Retrieved October 2, 2019, from theatlantic.com.

Mudde, C. (2016). The Study of Populist Radical Right Parties: Towards a Fourth Wave. C-REX Working Paper Series, 1, 1-23.

Mudde, C., \& Kaltwasser, C. R. (2017). Populism: A Very Short Introduction. Oxford University Press.

Riddell, M. (2016, July 23). Exclusive Interview with France's Youngest and Most Controversial MP: Marion Maréchal-Le Pen on Brexit, the Nice Attack, Gay Marriage and Her Aunt Marine. London: The Telegraph.

Schwarz, R. (2018). Democracy under Pressure: Polarization and Repression Are Increasing Worldwide (p. a). Brussels: Bertelsmann Stiftung.

The Berlusconisation of Italy. (2009, April 30). The Economist.

Wodak, R. (2015). The Politics of Fear: What Right-Wing Populist Discourses Mean. New York: Sage.

Wodak, R., \& Fairclough, N. (2013). Critical Discourse Analysis. London: Sage. 